University of Nebraska - Lincoln

DigitalCommons@University of Nebraska - Lincoln

\title{
Water and Bromide Recovery in Wick and Pan Lysimeters under Conventional and Zero Tillage
}

John P. Schmidt

United States Department of Agriculture, john.schmidt@ars.usda.gov

Henry Lin

Pennsylvania State University

Follow this and additional works at: https://digitalcommons.unl.edu/usdaarsfacpub

Part of the Agricultural Science Commons

Schmidt, John P. and Lin, Henry, "Water and Bromide Recovery in Wick and Pan Lysimeters under Conventional and Zero Tillage" (2008). Publications from USDA-ARS / UNL Faculty. 591.

https://digitalcommons.unl.edu/usdaarsfacpub/591

This Article is brought to you for free and open access by the U.S. Department of Agriculture: Agricultural Research Service, Lincoln, Nebraska at DigitalCommons@University of Nebraska - Lincoln. It has been accepted for inclusion in Publications from USDA-ARS / UNL Faculty by an authorized administrator of DigitalCommons@University of Nebraska - Lincoln. 


\title{
Water and Bromide Recovery in Wick and Pan Lysimeters under Conventional and Zero Tillage
}

\author{
John P. Schmidt ${ }^{1}$ and Henry Lin $^{2}$ \\ ${ }^{1}$ United States Department of Agriculture, Agricultural Research Service, \\ University Park, Pennsylvania, USA \\ ${ }^{2}$ Department of Crop and Soil Sciences, Pennsylvania State University, \\ University Park, Pennsylvania, USA
}

\begin{abstract}
Quantifying in situ solute transport through soils and the landscape has been widely acknowledged as important and yet challenging. The objective of this study was to evaluate water and bromide movement in no-tilled (NT) and conventionally tilled (CT) corn using two different types of in situ lysimeters-pan and capillary wickfor single rainfall events. Four zero-tension pan and four capillary-wick lysimeters were installed $1.2 \mathrm{~m}$ deep on opposite sides of four soil pits. Two were under NT corn, and two were under $\mathrm{CT}$ corn. Bromide $(\mathrm{Br})$ was either surface applied or applied with an initial 25 to $27 \mathrm{~mm}$ of irrigation (33 to $34 \mathrm{~g} \mathrm{Br} \mathrm{m}^{2}$ ). A total of 120 to $147 \mathrm{~mm}$ of irrigation was applied continuously at $8.8 \mathrm{~mm} \mathrm{~h}^{-1}$. Leachate was collected on $15 \mathrm{~min}$ intervals for $24 \mathrm{~h}$ and on greater intervals for up to $350 \mathrm{~h}$. Lysimeter discharge and $\mathrm{Br}$ concentration were determined for each interval. After drainage began and until rainfall was discontinued, the water drainage rate was, on average, greater in NT $\left(7.2 \mathrm{~mm} \mathrm{~h}^{-1}\right)$ than in $\mathrm{CT}\left(5.6 \mathrm{~mm} \mathrm{~h}^{-1}\right)$ based on results from the pan lysimeters. By contrast, the water drainage rate for the wick lysimeters was, on average, greater in CT $\left(7.3 \mathrm{~mm} \mathrm{~h}^{-1}\right)$ than in $\mathrm{NT}\left(3.0 \mathrm{~mm} \mathrm{~h}^{-1}\right)$. The wick lysimeter appears to have behaved as a sink under the CT conditions, likely representing water flow in smaller channels. Under NT conditions, greater discharge observed with the pan lysimeter implicates the response from larger channels as the conduit
\end{abstract}

Received 6 August 2006, Accepted 26 April 2007

Trade or manufacturers' names mentioned in the article are for information only and do not constitute endorsement, recommendation, or exclusion by the USDA-ARS.

Address correspondence to John P. Schmidt, USDA-ARS, Building 3702, Curtin Road, University Park, PA 16802, USA. E-mail: john.schmidt@ars.usda.gov 
for water flow. Flow-weighted mean $\mathrm{Br}$ concentration was less when $\mathrm{Br}$ was applied on the soil surface $\left(17.9 \mathrm{mg} \mathrm{L}^{-1}\right)$ than when $\mathrm{Br}$ was applied with the irrigation water $\left(50.6 \mathrm{mg} \mathrm{L}^{-1}\right)$. Implications from preferential flow studies are often determined based on a single method of evaluation for solute transport, which are likely subject to the limitation of the method used. This study illustrates that contrary to the conventional understanding about preferential flow in NT, water flow and $\mathrm{Br}$ transport to the 1.2-m depth was as great as or greater with CT than with NT based on the results from the wick lysimeters for single rainfall events.

Keywords: Pan lysimeters, preferential flow, tillage, wick lysimeters

\section{INTRODUCTION}

Zero-tension pan and wick lysimeters are similar approaches to measuring in situ water and solute movement in soils. Although installation and maintenance requirements are similar, the pan lysimeter sometimes suffers from low collection efficiency. Downward water movement can bypass pan lysimeters because tension around the pan might be greater than tension above the pan, resulting in low collection efficiency (Jemison and Fox 1992; Boll et al. 1991). Steenhuis et al. (1995) illustrated this by partitioning wick and pan lysimeters into $5 \times 5$ grids of individual collection compartments. Bromide $(\mathrm{Br})$ concentration for the pan lysimeter was greater near the center of the pan, whereas $\mathrm{Br}$ concentration for the wick lysimeter appeared to be randomly distributed spatially. Wick lysimeters have been shown to increase collection efficiency compared to pan lysimeters (Boll et al. 1991; Brandi-Dohrn et al. 1996) because the wick exerts tension on the soil above the wick lysimeter, collecting water from the soil matrix that might otherwise be diverted around a pan lysimeter. The collection efficiency for two wick lysimeters in a 1-month experiment by Boll et al. (1991) was $103 \%$ of water and $65 \%$ of Br compared to $25 \%$ and $7 \%$ for water and $\mathrm{Br}$, respectively, for a pan lysimeter. Brandi-Dorhn et al. (1996) observed between 66 and 80\% water collection efficiency using wick lysimeters in a 2-year study. Zhu, Fox, and Toth (2002) observed a water collection efficiency of $101 \%$ for wick lysimeters and $40 \%$ for pan lysimeters during 4 years of a 5-year study. During the fifth year, coinciding with an exceptionally wet and warm winter, collection efficiencies were much greater for the wick and pan lysimeters, as great as $175 \%$ for the wick and $87 \%$ for the pan. Collection efficiency provides an adjustment to long-term percolation estimates under field conditions, a mechanism with which to adjust for downward water movement not captured by the lysimeter.

Collection efficiency is determined by estimating percolate volume based on rainfall and estimating or measuring evapotranspiration (Zhu, Fox, and Toth 2002), then dividing leachate volume captured by the lysimeter by the estimate of percolate volume for a specific time period. Consequently, collection efficiency is a function of evapotranspiration, with the potential for 
greater impact on estimates of downward water movement for longer duration studies. For short duration studies (i.e., a single rainfall or irrigation event), evapotranspiration is negligible, and percolate volume is represented by leachate volume for the specific time period. For a short duration event, leachate volume primarily represents channel (or preferential) flow.

The simultaneous use of nonadsorbing and adsorbing tracers has demonstrated that solutes that typically adsorb to soil surfaces can move relatively quickly through a soil by channel flow. Rhodamine WT, a soil-adsorbing tracer, was detected in the tile water within 25 min after the start of irrigation containing the tracer (Everts et al. 1989). Although the Rhodamine WT peak concentration in the tile water occurred at the same time as the peak for the conservative tracers [nitrate $\left(\mathrm{NO}_{3}\right)$ and $\mathrm{Br}$ ] in this study (Everts et al. 1989), the Rhodamine WT concentration decreased to near background levels almost immediately with the cessation of irrigation, while the conservative tracer concentrations remained at a relatively elevated level. Kung et al. (2000) demonstrated similar results using the same tracers on larger tiledrained plots ( 18 by $65 \mathrm{~m}$ ) and included an evaluation of two irrigation intensities in no-tilled (NT) and conventionally tilled (CT) fields. Arrival time (to the tile outlet) was similar for both types of tracers, and they did not observe a difference between tillage practices.

Although Kung et al. (2000) indicated that preferential flow paths were behaving similarly between NT and CT systems when their study soils were wet, other researchers have indicated that tillage practices have an impact on preferential flow (Bicki and Guo 1991; Trojan and Linden 1994). Trojan and Linden (1994) suggested that different mechanisms may be controlling preferential flow depending on the antecedent soil moisture content and rainfall distribution pattern (e.g., intensity and duration).

Despite studies identifying preferential flow as a pathway for quickly moving adsorbing and nonadsorbing solutes through a soil, the implications of every facet of a complex soil system are difficult to verify. Wick and pan lysimeters have been shown to perform equally well, when most of the transport was occurring via channel flow in a clay loam soil (Steenhuis et al. 1995). Conversely, Zhu, Fox, and Toth (2002) indicated that collection efficiency for wick lysimeters was much greater than pan lysimeters for 4 years of a study when water flow was probably dominated by matrix flow. During large rainfall events, channel flow can move water and solutes quickly down the soil profile. Wick and pan lysimeters could perform equally well in quantifying channel flow during these short-duration events, yet this comparison has not be considered in the literature. The impact of channel flow during a rainfall event represents almost instantaneous displacement of solutes within the soil profile, with much slower matrix flow occurring between events. The objective of this study was to evaluate water and Br recovery with wick and pan lysimeters during and immediately after single rainfall events. Two different tillage practices, NT and CT, were considered, and two methods of applying the $\mathrm{Br}$, in the water or applied to the soil surface, were evaluated. 


\section{MATERIALS AND METHODS}

In situ zero-tension pan and capillary-wick lysimeters had been previously installed at the Russell E. Larson Agricultural Research Center of the Pennsylvania State University in central Pennsylvania. The soils at this site were classified as a Hagerstown silt loam (fine, mixed, semiactive, mesic Typic Hapludalfs), which developed from limestone residuum. Selected soil chemical and physical characteristics were provided by Jemison and Fox (1992).

A detailed description of pan lysimeter construction and installation was provided by Jemison and Fox (1992), and for the wick lysimeter by Zhu, Fox, and Toth (2002). A brief description is provided here. A lysimeter pit was excavated with a backhoe into which a plywood support structure was snugly fitted $(2.4 \mathrm{~m}$ deep $\times 1.22 \mathrm{~m} \times 1.22 \mathrm{~m})$. Lysimeter tunnels were excavated on opposite sides of the pit at a depth of $120 \mathrm{~cm}$ and laterally to a distance that provides sufficient room for each lysimeter and $30 \mathrm{~cm}$ between the near edge of the lysimeter and the pit wall. The pan lysimeter surface dimension was $76 \times 61 \mathrm{~cm}$. Each pan was filled with polypropylene beads. A polyvinyl chloride tube connected to the pan outflow port was used to carry leachate to a collection container. The wick lysimeter surface dimension was $30 \times 30 \mathrm{~cm}$ and included six $9.5 \mathrm{~mm}$ diameter (PEP 3/8), 20-strand fiberglass ropes supplied by Pepperell Braiding Co. (East Pepperell, Mass.). Wicks were frayed and evenly distributed across a Plexiglass ${ }^{\circledR}$ platform with a $3.2 \mathrm{~cm}$ diameter hole in the center. The wicks descended through this center hole enclosed in a flexible drainage hose, which discharged into a collection container. The vertical distance between the Plexiglass ${ }^{\circledR}$ top of the wick lysimeter and the bottom of the wick was $50 \mathrm{~cm}$, providing $50 \mathrm{~cm}$ of water tension on the soil. Both lysimeters were pressed against the tunnel ceiling using turnbuckle supports.

Four wick and four pan lysimeters, installed in four pits within a $22 \times 11-\mathrm{m}$ rectangular area, were selected for this study. The field above two pits was managed as NT and above the other two pits managed as CT. Although the pan lysimeters had been installed in 1988 and the wick lysimeters in 1995, they remained physically intact and actively collecting water.

The crop rotation at this site had been corn (Zea mays L.)-soybean [Glycine max (L.) Merr.] since 1997. Corn was grown in 2002 and soybean in 2003. Corn was planted in 2004 on May 11 at 71,000 seeds ha ${ }^{-1}$ for an intended population of 65,000 plants $\mathrm{ha}^{-1}$. Tillage consisted of chisel plow and seed preparation with a field cultivator for the CT treatments.

Rainfall simulations (irrigation) were conducted on 25 May and 16, 23, and 29 June 2004. Two low-intensity rainfall sprinklers developed by Sporre-Moeny, Lanyon, and Sharpley (2004) were used. The sprinkler design consisted of one inverted full-cone spray nozzle operating at $6.9 \times 10^{4} \mathrm{~Pa}$ mounted in the center of a $1.8 \times 1.8 \times 1.3-\mathrm{m}$ tall PVC pipe frame. The nozzle was facing up, located $45 \mathrm{~cm}$ above the soil surface. The 
pipe frames were placed immediately adjacent to and on both sides of the lysimeter pit, centered above the wick and pan lysimeters. Water pressure was monitored and adjusted for each sprinkler at $1 \mathrm{~m}$ from the nozzle. The flow coefficient of uniformity for this sprinkler was $97 \%$ (cup method), and the mean drop size diameter was $0.51 \mathrm{~mm}$ (oil method) (Sporre-Money, Lanyon, and Sharpley 2004). Maximum rainfall intensity was determined for this study by applying as much water as possible without generating runoff. During the first two h of the first event, rainfall intensity was as great as $12.5 \mathrm{~mm} \mathrm{~h}^{-1}$. This rainfall intensity exceeded infiltration (based on visual observations), so the intensity was adjusted to about $8.8 \mathrm{~mm} \mathrm{~h}^{-1}$ for the remainder of all simulations. Runoff was not observed at this rainfall intensity. The adjustment consisted of turning off the sprinkler for $5 \mathrm{~min}$ in 15 -min increments. The 5-min pause in rainfall also provided an opportunity to collect leachate samples.

Rainfall was measured hourly using four rain gauges standing upright on the soil surface within the area represented by each pipe frame and above the corners of each lysimeter but outside the vertical column represented by the lysimeter footprint. Average rainfall intensity on all four simulation dates $\left(\mathrm{n}=8\right.$ lysimeters) was $8.8 \mathrm{~mm} \mathrm{~h}^{-1}$, ranging from 8.5 to $9.2 \mathrm{~mm} \mathrm{~h}^{-1}$ (Table 1). This rainfall rate is comparable to the saturated hydraulic conductivity for this soil $\left(\mathrm{K}_{\mathrm{sat}}=8.5 \mathrm{~mm} \mathrm{~h}^{-1}\right)$ determined by Campbell and Fritton (1994). Although rainfall intensity was fairly constant for all events, cumulative rainfall ranged between $120 \mathrm{~mm}$ for the 25 May event to $147 \mathrm{~mm}$ for the 23 June event, because duration of events varied between 13 and $17 \mathrm{~h}$.

On 25 May, $\mathrm{KBr}$ was added with the first $25 \mathrm{~mm}$ of irrigation on a NT plot. Bromide concentration was $1300 \mathrm{mg} \mathrm{L}^{-1}$, corresponding to $33 \mathrm{~g} \mathrm{Br} \mathrm{m}^{-2}$. Irrigation (without $\mathrm{Br}$ ) continued for an additional $11 \mathrm{~h}$ for $120 \mathrm{~mm}$ total water applied (Table 1). A $20 \mathrm{~min}, 10 \mathrm{~mm}$ natural rainfall occurred $20 \mathrm{~h}$ after irrigation started, generating runoff (visually observed) and infiltration. Additional natural rainfall events during the $350 \mathrm{~h}$ of leachate collection for each simulation are noted with the results.

Table 1. Method of $\mathrm{Br}$ application and irrigation duration and rate for each simulation date

\begin{tabular}{lcclccc}
\hline Simulation & Tillage & $\begin{array}{c}\text { Br applied } \\
\left(\mathrm{g} \mathrm{m}^{-2}\right)\end{array}$ & $\begin{array}{c}\text { Method of } \\
\text { application }\end{array}$ & $\begin{array}{c}\text { Irrigation } \\
\text { duration } \\
(\mathrm{h})\end{array}$ & $\begin{array}{c}\text { irrigation } \\
\text { rate mm } \\
\left(\mathrm{mm} \mathrm{h}^{-1}\right)\end{array}$ & $\begin{array}{c}\text { Mean total } \\
\text { irrigation } \\
(\mathrm{mm})\end{array}$ \\
\hline 25 May & NT & 33 & With water & 13 & 9.2 & 120 \\
16 June & NT & 34 & On soil & 15 & 8.5 & 127 \\
23 June & CT & 35 & With water & 17 & 8.6 & 147 \\
29 June & CT & 34 & On soil & 15 & 8.8 & 131 \\
\hline
\end{tabular}


On 15 June, $\mathrm{KBr}$ was broadcast applied $\left(34 \mathrm{~g} \mathrm{Br} \mathrm{m}^{-2}\right)$ on the soil surface to a $3.3-\mathrm{m}^{2}$ area above the lysimeter of a second NT plot. The simulated rainfall event was begun on June 16, and no natural rainfall had occurred during the period between $\mathrm{Br}$ application and beginning of the simulation. Irrigation continued for $15 \mathrm{~h}$ for a total of $127 \mathrm{~mm}$.

On 23 June, $\mathrm{KBr}$ was added with the first $27 \mathrm{~mm}$ of rainfall on a $\mathrm{CT}$ plot. Bromide concentration was $1300 \mathrm{mg} \mathrm{L}^{-1}$, corresponding to $35 \mathrm{~g} \mathrm{Br} \mathrm{m}^{-2}$. Irrigation (without $\mathrm{Br}$ ) continued for a total of $17 \mathrm{~h}$ and a total rainfall of $147 \mathrm{~mm}$.

On 28 June, $\mathrm{KBr}$ was broadcast applied to the soil surface of a second $\mathrm{CT}$ plot, at the same rate and using the same method as described previously. The irrigation event was begun on June 29 (no natural rainfall had occurred during the period between $\mathrm{Br}$ application and beginning of simulation), continuing for $15 \mathrm{~h}$, and $131 \mathrm{~mm}$ total water was applied.

Lysimeters were not draining any water for $24 \mathrm{~h}$ prior to the beginning of each rainfall simulation. Drainage from each lysimeter was checked on 15-min intervals. When more then $30 \mathrm{~mL}$ of leachate was generated, the entire sample was collected, placed in a plastic bottle, and capped. If less than $30 \mathrm{~mL}$ of leachate was generated, the sample remained in the collection bottle until the next 15 -min interval. Samples during the first $24 \mathrm{~h}$ were initially stored in a cooler, stored at $4{ }^{\circ} \mathrm{C}$ within $24 \mathrm{~h}$ of beginning the simulation event, filtered, and analyzed for $\mathrm{Br}$ within 8 weeks of the first event. For the latter two simulation events, samples from the first $24 \mathrm{~h}$ were filtered within $2 \mathrm{~h}$ of collection and then stored at $4{ }^{\circ} \mathrm{C}$ (within $24 \mathrm{~h}$ ) until analysis. Between 24 and $350 \mathrm{~h}$ after the beginning of each simulation, leachate samples were collected on increasingly greater intervals, and samples were stored, filtered, and analyzed as described previously. Although leachate was sometimes still accumulating after $350 \mathrm{~h}$ (though very slowly), collection was terminated because natural rainfall events increasingly masked the impact of the rainfall simulations. Sample collection for the 29 June event was terminated after $173 \mathrm{~h}$ because of a $40 \mathrm{~mm}$ natural rainfall event that had occurred just prior to $173 \mathrm{~h}$, which did not contribute to drainage in either lysimeters but was likely to affect the wick lysimeter if sampling had continued.

Bromide concentration was determined by flow injection analysis using a Lachat autoanalyzer (Quick Chem FIA + 8000 Series, Lachat Instruments, Loveland, C.1.), following the method described by Bogren and Smith (2003).

Water recovery was determined as volume of water accumulated as leachate divided by water applied during the simulation or received as natural rainfall (based on lysimeter surface area or footprint) within $350 \mathrm{~h}$ (173 for the 29 June event) of beginning the simulation. Bromide recovered in the leachate was determined by summing the mass of $\mathrm{Br}$ accumulated (volume of leachate $\times \mathrm{Br}$ concentration) and dividing by $\mathrm{Br}$ mass applied. Mean flow-weighted $\mathrm{Br}$ concentration was determined as $\mathrm{Br}$ mass recovered divided by accumulated volume of leachate.

Gravimetric soil water content was determined from samples collected at the beginning of each event. One 5-cm diameter core was collected within 
$10 \mathrm{~m}$ of each lysimeter pit using an open-face soil auger. Samples were collected to a $1.2-\mathrm{m}$ depth in $15-\mathrm{cm}$ increments, sealed in a plastic bag, weighed, dried at $105^{\circ} \mathrm{C}$ for 4 days, and weighed again.

Statistical analyses were performed using SAS (SAS Institute Inc. 1999). PROC TTEST was used to determine the difference between means for flowweighted $\mathrm{Br}$ concentration and water recovery. Equality of variance between means was evaluated using PROC TTEST. Mean rate of leachate outflow was determined as the slope of a linear regression of cumulative leachate as a function of time between the first leachate sample and the leachate sample corresponding to when irrigation was terminated. PROC TTEST was used to determine the difference between mean rates of leachate outflow.

\section{RESULTS AND DISCUSSION}

Gravimetric soil water content ranged between 0.21 and $0.32 \mathrm{~g} \mathrm{~g}^{-1}$ throughout the 0 - to $1.2-\mathrm{m}$ depth at the beginning of each simulated rainfall event (Table 2). Water content was slightly greater in the lower part of the soil profile and generally similar among dates, although slightly drier for the 29 June event-probably a consequence of greater water uptake during this later stage of plant development. These values represent soil moisture conditions that are less than field capacity but sufficiently moist so that cracks were not visually present on the soil surface.

\section{Water Drainage}

Leachate outflow in the pan lysimeters on 25 May and 16 June was nearly identical during the $13 \mathrm{~h}$ after irrigation began (Figure 1a), representing results under NT. Rapid leachate outflow continued for an additional $2 \mathrm{~h}$ for the 16 June event, corresponding to the additional $2 \mathrm{~h}$ of irrigation applied

Table 2. Gravimetric soil water content at the beginning of each simulation

\begin{tabular}{lcccc}
\hline Depth $(\mathrm{cm})$ & 25 May $\left(\mathrm{g} \mathrm{g}^{-1}\right)$ & 16 June $\left(\mathrm{g} \mathrm{g}^{-1}\right)$ & 23 June $\left(\mathrm{g} \mathrm{g}^{-1}\right)$ & 29 June $\left(\mathrm{g} \mathrm{g}^{-1}\right)$ \\
\hline $0-15$ & 0.22 & 0.24 & 0.26 & 0.21 \\
$15-30$ & 0.22 & 0.24 & 0.24 & 0.21 \\
$30-45$ & 0.23 & 0.25 & 0.23 & 0.21 \\
$45-60$ & 0.24 & 0.24 & 0.24 & 0.22 \\
$60-75$ & 0.25 & 0.25 & 0.24 & 0.23 \\
$75-90$ & 0.27 & 0.26 & 0.25 & 0.24 \\
$90-105$ & 0.30 & 0.28 & 0.28 & 0.24 \\
$105-120$ & - & 0.32 & 0.25 & 0.21 \\
\hline
\end{tabular}



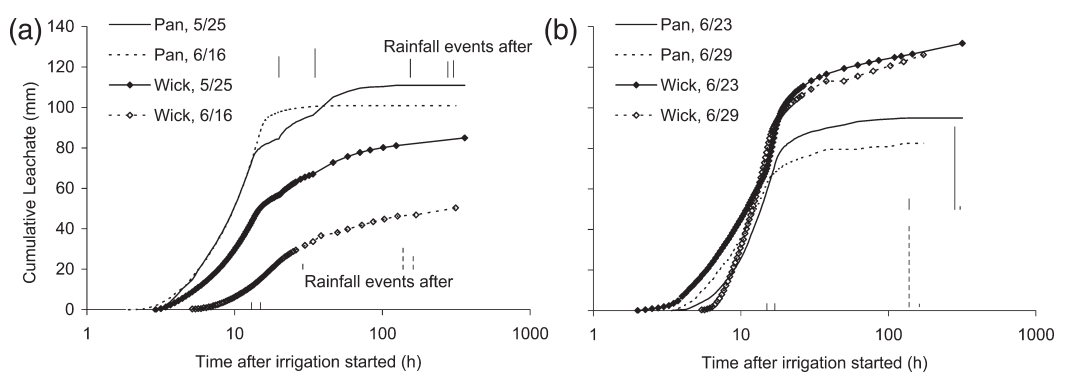

Figure 1. Accumulated discharge in pan and wick lysimeters for (a) no-till (NT) plots and (b) conventionally tilled (CT) plots. Natural rainfall events are identified by vertical bars, and the length of each bar represents rainfall amount. Tick marks inside the $\mathrm{x}$-axis are at (a) 13 and $15 \mathrm{~h}$ and (b) 15 and $17 \mathrm{~h}$.

for this event (Table 1). Within $1 \mathrm{~h}$ of terminating irrigation, leachate outflow in both pan lysimeters under NT had decreased to less than 50\%, decreasing from more than $7.2 \mathrm{~mm} \mathrm{~h}^{-1}$ to less than $3.6 \mathrm{~mm} \mathrm{~h}^{-1}$. Within $19 \mathrm{~h}$ of initiating irrigation, 76 and $96 \%$ (25 May and 16 June, respectively) of the total drainage had occurred in the pan lysimeters under NT. Two natural rainfall events after the 25 May event, 10 and $14 \mathrm{~mm}$, increased leachate outflow at 20 and $34 \mathrm{~h}$, respectively (Figure 1a). Additional later and smaller rainfalls after both irrigation events did not increase leachate outflow as much as these two larger events (Figure 1a). With the final leachate collection, outflow for the pan lysimeters had decreased to $0.002 \mathrm{~mm} \mathrm{~h}^{-1}$ and zero for the 25 May and 16 June irrigation events, respectively. Total irrigation and rainfall during the $350 \mathrm{~h}$ after irrigation began was 167 and $144 \mathrm{~mm}$ for the pan lysimeters on 25 May and 16 June, respectively (Table 3). Sixty-six and 70\%, respectively, of this total was recovered with the pan lysimeters.

The percentage of precipitation collected by the lysimeter (PPL) was relatively great for this one-time, longer-duration event than other results observed at this field site. Zhu, Fox, and Toth (2002) indicated that PPL for this study site ranged from 22 to $25 \%$ (for nine lysimeters) under NT for 4 of 5 years. During a much wetter year observed during this previous study, annual PPL was about 50\%. The much greater PPL (66 to 70\%) observed in our study for the pan lysimeters can be explained in the context of the temporal differences between these two studies. While Zhu, Fox, and Toth (2002) were monitoring drainage throughout the year, the current study's timeframe is only $350 \mathrm{~h}$ after a single, long irrigation event. As additional smaller precipitation events accrue during an entire year, similar to the natural rainfall events that were observed after $100 \mathrm{~h}$ in this study (Figure 1a), these additional small precipitation events do not always coincide with additional drainage in a pan lysimeter. Rainfall events for which there is not sufficient water to generate channel flow will not contribute to the PPL but will contribute to matrix flow, thus decreasing the PPL. 
Table 3. Irrigation, rainfall, and water recovery for pan and wick lysimeters, under no-till (NT) and conventional tillage (CT)

\begin{tabular}{|c|c|c|c|c|c|c|c|c|c|c|c|c|}
\hline \multirow{2}{*}{$\begin{array}{l}\text { Irrigation } \\
\text { date }\end{array}$} & \multirow[b]{2}{*}{ Tillage } & \multicolumn{2}{|c|}{$\begin{array}{l}\text { Total irrigation } \\
\quad(\mathrm{mm})\end{array}$} & \multirow{2}{*}{$\begin{array}{l}\text { Additional rainfall } \\
\text { within } 350 \mathrm{~h}(\mathrm{~mm})\end{array}$} & \multicolumn{2}{|c|}{$\begin{array}{l}\text { Irrigation plus } \\
\text { rainfall within } \\
350 \mathrm{~h}(\mathrm{~mm})\end{array}$} & \multicolumn{2}{|c|}{$\begin{array}{l}\text { Drainage } \\
\text { within } 350 \mathrm{~h} \\
\quad(\mathrm{~mm})\end{array}$} & \multicolumn{2}{|c|}{$\begin{array}{c}\text { Water recovery } \\
(\%)\end{array}$} & \multicolumn{2}{|c|}{$\begin{array}{l}\text { Mean outflow } \\
\text { during irriga- } \\
\text { tion }\left(\mathrm{mm} \mathrm{h}^{-1}\right)\end{array}$} \\
\hline & & Pan & Wick & & Pan & Wick & Pan & Wick & Pan & Wick & Pan & Wick \\
\hline 25 May & NT & 118 & 123 & 49 & 167 & 171 & 111 & 85 & 66 & 50 & 7.4 & 4.4 \\
\hline 16 June & $\begin{array}{c}\text { NT } \\
\text { Mean }\end{array}$ & 124 & 129 & 20 & 144 & 149 & 101 & 50 & $\begin{array}{l}70 \\
68^{a, b}\end{array}$ & $\begin{array}{l}34 \\
42^{a, c}\end{array}$ & $\begin{array}{l}7.1^{d} \\
7.2^{d}\end{array}$ & $\begin{array}{l}1.6 \\
3.0^{e}\end{array}$ \\
\hline 23 June & CT & 146 & 149 & 47 & 193 & 196 & 95 & 132 & 49 & 67 & 5.7 & 5.8 \\
\hline 29 June & $\begin{array}{c}\text { CT } \\
\text { Mean }\end{array}$ & 129 & 134 & 42 & 171 & 176 & 82 & 126 & $\begin{array}{l}48 \\
49^{f, b}\end{array}$ & $\begin{array}{l}72 \\
69^{f, c}\end{array}$ & $\begin{array}{l}5.6 \\
5.6^{d}\end{array}$ & $\begin{array}{l}8.7 \\
7.3^{e}\end{array}$ \\
\hline
\end{tabular}

${ }^{a}$ T-test, equal variance, $\mathrm{H}_{0}: \mathrm{P}>\mathrm{T}=0.087$.

${ }^{b}$ T-test, equal variance, $\mathrm{H}_{0}: \mathrm{P}>\mathrm{T}=0.011$.

${ }^{c} \mathrm{~T}$-test, equal variance, $\mathrm{H}_{0}: \mathrm{P}>\mathrm{T}=0.082$

${ }^{d}$ T-test, equal variance, $\mathrm{H}_{0}: \mathrm{P}>\mathrm{T}=0.006$.

${ }^{e}$ T-test, equal variance, $\mathrm{H}_{0}: \mathrm{P}>\mathrm{T}=0.091$

${ }^{f}$ T-test, equal variance, $\mathrm{H}_{0}: \mathrm{P}>\mathrm{T}=0.014$. 
Mean leachate outflow during irrigation for the wick lysimeters under NT $\left(3.0 \mathrm{~mm} \mathrm{~h}^{-1}\right)$ was less than mean leachate outflow for the pan lysimeters under NT (7.2 $\mathrm{mm} \mathrm{h}^{-1}$; Table 3). Although outflow for the pan lysimeters decreased to less than $50 \%$ within $1 \mathrm{~h}$ of terminating irrigation, outflow for the wick lysimeters decreased more slowly, requiring $2.5 \mathrm{~h}$ on 25 May and $7.5 \mathrm{~h}$ on 16 June to decrease to less than $50 \%$ of outflow observed at the time irrigation was terminated (Figure 1a). The smaller rate and slower decrease (after irrigation was terminated) in drainage suggest that the wick lysimeters in NT were draining channels with smaller effective diameters and longer and more tortuous paths than channels draining to the pan lysimeters. Outflow for the wick lysimeters for the final observation was 0.31 and $0.02 \mathrm{~mm} \mathrm{~h}^{-1}$ for 25 May and 16 June, respectively. These final observations were considerably less than $\mathrm{K}_{\mathrm{sat}}\left(8.5 \mathrm{~mm} \mathrm{~h}^{-1}\right)$ for this soil but greater than that observed for the pan lysimeters in NT, thus representing matrix flow and indicating that a longer collection period would have increased the PPL of the wick lysimeters in NT. The two larger natural rainfall events after the 25 May irrigation increased outflow in the wick lysimeter (Figure 1a), similar to results observed for the pan lysimeter. The other, smaller rainfall events did not result in any inflection of outflow for either irrigation events under NT (Figure 1a). Total rainfall and irrigation was $171 \mathrm{~mm}$ on 25 May and $149 \mathrm{~mm}$ on 16 June, while mean water recovery for the wick lysimeters was only $42 \%$, much less than the $68 \%$ water recovery observed for the pan lysimeters on these dates (Table 3). Zhu, Fox, and Toth (2002) reported PPLs for wick lysimeters $(n=9)$ that were slightly greater than this, ranging between 44 and $53 \%$ for NT. The timeframe of the current study has the opposite affect on the PPL calculated for the wick lysimeters, as compared to results observed for the pan lysimeters. With a longer duration of drainage collection, the additional drainage recovered as matrix flow would increase PPL of a wick lysimeter.

Two subsequent irrigation events, on 23 and 29 June, were conducted within 2 weeks of the 16 June event, yet leachate outf low for the wick lysimeters under CT (Figure 1b; Table 3) was much greater than outflow observed for the wick lysimeters under NT (Figure 1a; Table 3). Mean outflow for the wick lysimeters under CT was $7.3 \mathrm{~mm} \mathrm{~h}^{-1}$ during irrigation, which was similar to mean outflow for the pan lysimeters under NT and $4.3 \mathrm{~mm} \mathrm{~h}^{-1}$ greater than the wick lysimeters under NT (Table 3). After irrigation was terminated, outflow decreased relatively quickly for the wick lysimeters, decreasing to less than $50 \%$ within $1.75 \mathrm{~h}$ on 23 and 29 June. The final leachate collection was recorded $320 \mathrm{~h}$ after irrigation began on 23 June and $173 \mathrm{~h}$ for the 29 June event. By this time, outflow for the wick lysimeters had decreased to 0.006 and $0.015 \mathrm{~mm} \mathrm{~h}^{-1}$, respectively. A $40-\mathrm{mm}$ natural rainfall event was recorded within $24 \mathrm{~h}$ of the final leachate collection, corresponding to a very slight inflection (increase) in cumulative leachate (Figure 1b). Total irrigation and rainfall was 196 and 176 (23 and 29 June, respectively) for the wick lysimeters under CT. Mean water recovery with 
the wick lysimeters was $69 \%$ under CT, which was comparable to the pan lysimeters under NT (68\%) but much greater than the wick lysimeters under NT (42\%; Table 3).

Greater drainage for the wick lysimeter under CT $\left(7.3 \mathrm{~mm} \mathrm{~h}^{-1}\right)$ compared to the wick lysimeter under NT $\left(3.0 \mathrm{~mm} \mathrm{~h}^{-1}\right.$; Table 3) differs from Zhu, Fox, and Toth's (2002) conclusion that there was no difference in drainage between CT and NT. One possible explanation to account for the greater drainage observed for the wick lysimeter under CT in the current study might be related to the disruption of flow channels in the tilled surface horizon as a consequence of the spring tillage. The wick lysimeter might behave as a sink for a larger proportion of area (compared to the lysimeter footprint) of the tilled surface horizon, because the disruption of larger channels in the surface would allow the water potential to increase in the surface soil (more than what might be expected under NT). As water potential increases in the CT surface soil, the network of smaller channels below the tilled surface become active in moving water down the soil profile to the wick lysimeter. Zhu, Fox, and Toth (2002) attributed the oversampling by wick lysimeters to the possibility that the samplers were behaving as sinks, when more drainage had been recorded than precipitation observed during a very wet 1997 season. Holder et al. (1991) attributed this overestimation of drainage to converging flow lines toward the sampler when water potential was high, describing the wick sampler as a possible sink.

Mean outflow for the pan lysimeters under CT was $5.6 \mathrm{~mm} \mathrm{~h}^{-1}$ during irrigation, $1.6 \mathrm{~mm} \mathrm{~h}^{-1}$ less than observed for the pan lysimeters under NT (Table 3). Less than $1 \mathrm{~h}$ after irrigation was terminated, outflow quickly decreased to less than $50 \%$ of outflow observed prior to terminating irrigation. On the final leachate collection, within $24 \mathrm{~h}$ of a 40-min natural rainfall, neither pan lysimeters under CT yielded any outflow. Total irrigation and rainfall during the irrigation and subsequent sampling period was 196 and $176 \mathrm{~mm}$ for 23 and 29 June, respectively. Water recovery for the pan lysimeters under CT (49\%) was less than that observed for the pan lysimeters under NT (68\%) and less than observed for the wick lysimeters under CT $(69 \%)$ (Table 3). Less water recovery in the pan lysimeter under CT, as compared to the pan lysimeter under NT, can be attributed to the disruption of larger channels that were conduits under NT.

Wick lysimeters recovered $27 \%$ more water under CT than compared to NT, whereas pan lysimeters recovered $19 \%$ less water under CT than under NT (Table 3). Under CT, wick lysimeters recovered $20 \%$ more water then pan lysimeters, but under NT, $26 \%$ less water was recovered with wick lysimeters than pan lysimeters. Wick lysimeters were more effective in recovering water under CT, whereas pan lysimeters were more effective under NT conditions for this single rainfall event. Difference in the performance of the wick and pan lysimeters under these two tillage scenarios is probably a consequence of the temporal scale and the impact of tillage on the larger channels-those conducting water to the pan lysimeters. Tillage (CT) 
disrupts the network of larger channels, and less drainage was observed with the pan lysimeter under CT compared to NT. Disruption of the larger channels may also be conducive to an increase in water potential in the tilled surface during irrigation, which could increase the conductance of the smaller channels and effectively make the wick lysimeter a sink under CT.

\section{Bromide Concentration}

Potassium bromide was applied with the first 25 and $27 \mathrm{~mm}$ of irrigation on 25 May and 23 June, respectively, each representing NT or CT. Within 4 h of initiating irrigation on 23 June, $\mathrm{Br}$ concentration in the wick lysimeter leachate reached $907 \mathrm{mg} \mathrm{L}^{-1}$ (Figure 2a), only $393 \mathrm{mg} \mathrm{L}^{-1}$ less than $\mathrm{Br}$ concentration in the initial $27 \mathrm{~mm}$ of irrigation water. Bromide concentration in the pan lysimeter leachate on 23 June reached a peak of $59.4 \mathrm{mg} \mathrm{L}^{-1}$ within $4 \mathrm{~h}$, before sharply decreasing and then slowly increasing until $17 \mathrm{~h}$, when irrigation was terminated. The distinct peak observed at $4 \mathrm{~h}$ on 23 June (CT) was not observed on 25 May (NT), but $\mathrm{Br}$ concentration for the 25 May event increased in the leachate to 70.3 and $47.3 \mathrm{mg} \mathrm{L}^{-1}$ for the pan and wick lysimeters, respectively, then decreased after irrigation was terminated at $13 \mathrm{~h}$. Flow-weighted mean $\mathrm{Br}$ concentration was $47.8 \mathrm{mg} \mathrm{L}^{-1}$ in leachate collected when $\mathrm{Br}$ was applied with the initial irrigation water. This represented $15.6 \%$ of the total amount of applied $\mathrm{Br}$ (Table 4). These results are similar to those observed by Kung et al. (2000), who applied $\mathrm{Br}$ with the water in a $7.5 \mathrm{~h}$ irrigation event at a rate of $7.5 \mathrm{~mm} \mathrm{~h}^{-1}$. Kung et al. (2000) first observed $\mathrm{Br}$ in the tile drainage within $2 \mathrm{~h}$ of when a $\mathrm{Br}$ pulse was injected into the irrigation stream, reaching a peak concentration near $300 \mathrm{mg} \mathrm{L}^{-1}$ and then decreasing lognormally after that initial concentration spike. Increasing $\mathrm{Br}$ concentration through 13 to $17 \mathrm{~h}$ (Figure 2a) in
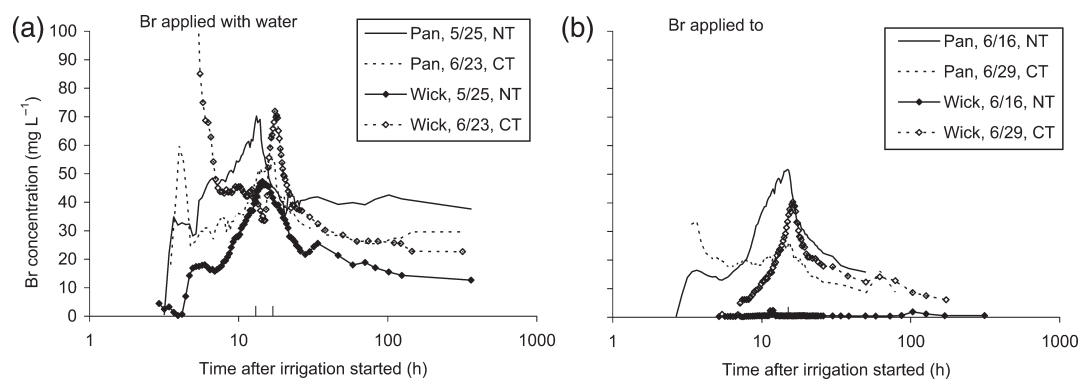

Figure 2. Bromide concentration in the lysimeter leachate for (a) Br applied with irrigation water and (b) Br applied to soil. Tick marks inside the x-axis are at (a) 13 and $17 \mathrm{~h}$ and (b) $15 \mathrm{~h}$. For some events, the $\mathrm{Br}$ response terminated when discharged ceased. 
Table 4. Bromide leached to $1.2 \mathrm{~m}$ within $350 \mathrm{~h}$ after the start of irrigation

\begin{tabular}{|c|c|c|c|c|c|c|c|c|c|c|c|}
\hline \multirow[b]{2}{*}{ Date } & \multirow[b]{2}{*}{ Tillage } & \multirow[b]{2}{*}{$\begin{array}{l}\text { Application } \\
\text { method }\end{array}$} & \multirow[b]{2}{*}{$\begin{array}{l}\text { Bromide } \\
\text { applied }\end{array}$} & \multicolumn{2}{|c|}{$\begin{array}{l}\text { Bromide recov- } \\
\text { ered }\left(\mathrm{g} \mathrm{m}^{-2}\right)\end{array}$} & \multicolumn{3}{|c|}{$\begin{array}{l}\text { Bromide recovered } \\
\text { (\% of applied) }\end{array}$} & \multicolumn{3}{|c|}{$\begin{array}{c}\text { Flow-weighted } \\
\text { Mean } \mathrm{Br} \text { conc. }\left(\mathrm{mg} \mathrm{L}^{-1}\right)\end{array}$} \\
\hline & & & & Pan & Wick & Pan & Wick & Mean & Pan & Wick & Mean \\
\hline 25 May & NT & With water & 33 & 5.2 & 2.14 & 15.9 & 6.5 & & 47.2 & 25.2 & \\
\hline \multirow[t]{2}{*}{23 June } & CT & With water & 35 & 3.8 & 10.41 & 10.9 & 29.8 & & 40.0 & 79.0 & \\
\hline & & Mean & & & \multicolumn{2}{|c|}{13.4} & 18.1 & $15.6^{a}$ & 43.6 & 52.1 & $47.8^{b}$ \\
\hline 16 June & NT & On soil & 34 & 3.2 & 0.03 & 9.3 & 0.1 & & 31.5 & 0.6 & \\
\hline \multirow[t]{2}{*}{29 June } & $\mathrm{CT}$ & On soil & 34 & 1.6 & 2.31 & 4.7 & 6.8 & & 19.3 & 18.3 & \\
\hline & & Mean & & & \multicolumn{2}{|c|}{7.0} & 3.4 & $5.2^{a}$ & 25.4 & 9.5 & $17.4^{b}$ \\
\hline
\end{tabular}

${ }^{a}$ T-test, equal variance, $\mathrm{H}_{0}: \mathrm{P}>\mathrm{T}=0.108$.

${ }^{b} \mathrm{~T}$-test, equal variance, $\mathrm{H}_{0}: \mathrm{P}>\mathrm{T}=0.058$. 
this study was probably a consequence of the greater amount, and longer duration, of $\mathrm{Br}$ application. Bromide was applied with the irrigation water for the first 25 to $27 \mathrm{~mm}$ of water (Table 1).

When $\mathrm{Br}$ was added on the soil surface, less $\mathrm{Br}$ was observed in the leachate, suggesting that results observed when tracers are placed with the irrigation water may overestimate the susceptibility for movement in the soil. For the 16 and 29 June events, $\mathrm{KBr}$ was applied to the soil surface 1 day before irrigating, each representing NT or CT. Similar to when $\mathrm{Br}$ was applied with the initial irrigation water (Figure $2 \mathrm{a}$ ), $\mathrm{Br}$ concentration in the pan lysimeter leachate reached a peak when irrigation was terminated at $15 \mathrm{~h}$, then decreased (Figure 2b). For the 16 June event (NT), the 15-h Br concentration $\left(51.7 \mathrm{mg} \mathrm{L}^{-1}\right)$ represented a primary peak, which occurred after a secondary peak $\left(16.5 \mathrm{mg} \mathrm{Br} \mathrm{L}^{-1}\right)$ observed at $3.7 \mathrm{~h}$. The primary peak (33.6 $\mathrm{mg} \mathrm{L}^{-1}$ ) observed for the pan lysimeter leachate on 29 June (CT) occurred at $3.7 \mathrm{~h}$ and was followed by a secondary peak $\left(26.0 \mathrm{mg} \mathrm{L}^{-1}\right)$ observed at $15 \mathrm{~h}$. Bromide concentration $\left(40.3 \mathrm{mg} \mathrm{L}^{-1}\right)$ in the leachate of the wick lysimeter under CT (29 June) peaked at $1.2 \mathrm{~h}$ after the termination of irrigation (Figure 2b). For the 16 June irrigation, $\mathrm{Br}$ concentration in the wick lysimeter leachate under NT remained relatively low, reaching only $2.4 \mathrm{mg} \mathrm{L}^{-1}$ at $12 \mathrm{~h}$ after initiating irrigation ( $3 \mathrm{~h}$ before irrigation was terminated). Flow-weighted mean $\mathrm{Br}$ concentration in the leachate was $17.4 \mathrm{mg} \mathrm{L}^{-1}$ when $\mathrm{Br}$ was applied on the soil surface, $30.4 \mathrm{mg} \mathrm{L}^{-1}$ less than observed in the leachate when $\mathrm{Br}$ was applied with the initial irrigation water (Table 4). This represented 5.2\% of the applied $\mathrm{Br}$ and $67 \%$ less than the $\mathrm{Br}$ leached to $1.2 \mathrm{~m}$ when $\mathrm{Br}$ was applied with irrigation water. When $\mathrm{Br}$ was applied with the irrigation water, $\mathrm{Br}$ reached the 1.2-m depth more quickly and at greater concentration than when $\mathrm{Br}$ was applied on the soil surface.

\section{CONCLUSIONS}

Results from this study illustrate several points to consider for the implications of tracer studies and the likelihood of groundwater contamination from agricultural fertilizers and pesticides.

Drainage rates for a single rainfall event were greater in NT compared to CT when the evaluation was based on results from a pan lysimeter (Figure 1). Shipitalo, Edwards, and Redmond (1994) reached this same conclusion using pan lysimeters. This result is typically attributed to the likelihood of greater channel flow when natural channels (e.g., worm holes) are more likely to remain intact and behave as a conduit for water under a NT system. In contrast to these results, when considering results from the wick lysimeters, drainage rates were greater under CT (Figure 1b) than NT (Figure 1a; Table 3). The high drainage rate with the wick lysimeters in CT was perhaps surprising. On 29 June, the drainage rate with the wick lysimeter 
(CT) was as great as the rainfall rate, suggesting that the smaller pores typically active with wick lysimeters were very efficient in transmitting water from the surface to the 1.2-m depth. The confounding effect between the type of sampling device (wick or pan lysimeter) and tillage system (NT or CT) suggests that definitive conclusions about channel flow in NT may not be as simple as stating that there is more channel flow in NT than CT because there is less disturbance of the natural channels.

Although the results from this study do not indicate that there was more channel flow under NT compared to CT, they do support the concept that channels are behaving as conduits for water and $\mathrm{Br}$, because in every instance water and $\mathrm{Br}$ reached the 1.2-m depth at a rate much faster than $\mathrm{K}_{\text {sat }}\left(8.5 \mathrm{~mm} \mathrm{~h}^{-1}\right)$.

Applying $\mathrm{Br}$ with the irrigation water, as opposed to a surface application, translated to greater $\mathrm{Br}$ concentration in the leachate, indicating slightly less interaction with the soil matrix as the $\mathrm{Br}$ and water moved through the soil profile when $\mathrm{Br}$ was applied with the irrigation water. These results suggest that applying a tracer with irrigation water will provide elevated estimates of tracer leached compared to applying a tracer on the soil surface.

Implications from preferential flow studies are often determined based on a single method of evaluation (e.g., tile drain, suction cup lysimeters, pan lysimeters, or wick lysimeters); however, results from this study suggest that a certain measure of caution must be dispensed with these interpretations. Contrary to conventional understanding that more preferential flow occurs under NT, translocation of water and $\mathrm{Br}$ to the 1.2-m depth was as great as or greater with CT than with NT when evaluating results from the wick lysimeters.

\section{REFERENCES}

Bicki, T.J. and Guo, L. (1991) Tillage and simulated rainfall intensity effect on bromide movement in an Argiudoll. Soil Sci. Soc. Am. J., 55: 794-799.

Bogren, K. and Smith, P. (2003) Determination of Bromide by Flow Injection Analysis: QuickChem Method 10-135-21-2-B FIA Methodology; Lachat Instruments: Loveland, Col.

Boll, J., Selker, J.S., Nijssen, B.M., Steenhuis, T.S., Van Winkle, J., and Jolles, E. (1991) Water quality sampling under preferential flow conditions. In Lysimeters for Evapotranspiration and Environmental measurement: Proceedings of the ASCE International Symposium on Lysimetry; Allen, R.G., Howell, T.A., Pruitt, W.O., Walter, I.A. and Jensen, M.E. (eds.); ASCE: New York, 290-298.

Brandi-Dohrn, F.M., Dick, R.P., Hess, M., and Selker, J.S. (1996) Field evaluation of passive capillary samplers. Soil Sci. Soc. Am. J., 60: 1705-1713.

Campbell, C.M. and Fritton, D.D. (1994) Factors affecting the field-saturated hydraulic conductivity measured by the borehole permeameter technique. Soil Sci. Soc. Am. J., 58: $1354-1357$.

Everts, C.J., Kanwar, R.S., Alexander, E.C. Jr. and Alexander, S.C. (1989) Comparison of tracer mobilities under laboratory and field conditions. J. Environ. Qual., 18: 491-498. 
Holder, M., Brown, K.W., Thomas, J.C., Zabcik, D., and Murray, H.E. (1991) Capillary-wick unsaturated zone soil pore water sampler. Soil Sci. Soc. of Am. J., 55: $1195-1202$.

Jemison, J.M. Jr. and Fox R.H. (1992) Estimation of zero-tension pan lysimeter collection efficiency. Soil Sci., 154: 85-94.

Kung, K.J.S., Steenhuis, T.S., Kladivko, E.J., Gish, T.J., Bubenzer, G., and Helling, C.S. (2000) Impact of preferential flow on the transport of adsorbing and non-adsorbing tracers. Soil Sci. Soc. Am. J., 64: 1290-1296.

SAS Institute Inc. 1999. SAS/STAT user's guide, version 8; SAS Institute, Inc: Cary, N.C. Available at http://v8doc.sas.com/sashtml/(Accessed 21 February 2006). .

Shipitalo, M.J., Edwards, W.M., and Redmond, C.E. (1994) Comparison of water movement and quality of earthworm burrows and pan lysimeters. J. Environ. Qual., 23: 1345-1351.

Sporre-Moeny, J.L., Lanyon, L.E., and Sharpley, A.N. (2004) Low-intensity sprinkler for evaluating phosphorus transport from different landscape positions. Appl. Eng. Agric., 20: 599-604.

Steenhuis, T.S., Boll, J., Jolles, E., and Selker, J.S. (1995) Field evaluation of wick and gravity pan samplers. In Handbook of Vadose Zone Characterization and Monitoring; Wilson, L.G., Everett, L.G. and Collen, S.J. (eds.); CRC Press.: Boca Raton, 629-638.

Trojan, M.D. and Linden, D.R. (1994) Tillage, residue, and rainfall effects on movement of an organic tracer in earthworm-affected soils. Soil Sci. Soc. Am. J., 58: $1489-1494$.

Zhu, Y., Fox, R.H., and Toth, J.D. (2002) Leachate collection efficiency of zero-tension pan and passive capillary fiberglass wick lysimeters. Soil Sci. Soc. Am. J., 66: 37-43. 